\title{
Substrate-Dependent Differences in Production of Extracellular Matrix Molecules by Squamous Carcinoma Cells and Diploid Fibroblasts
}

\author{
James Varani,* Suzanne E. G. Fligiel, Dennis R. Inman, David L. Helmreich, \\ Matthew J. Bendelow, and William Hillegas \\ Department of Pathology, University of Michigan Medical School, Ann \\ Arbor, Michigan 48109, Solohill Engineering, Inc., Ann Arbor, Michigan \\ 48104, and Department of Pathology, VAMC-Wayne State University, Allen \\ Park, Michigan 48101
}

Accepted for publication July 5, 1988

Two human squamous carcinoma cell lines and human diploid fibroblasts were examined for the production of extracellular matrix (ECM) molecules including fibronectin (FN), laminin (LN), and thrombospondin (TSP) when grown on a number of different substrates. The substrates used included glass, plastic, collagen (gelatin), and DEAE-dextran. Levels of TSP as indicated by enzyme-linked immunosorbent assay did not vary significantly as a function of substrate. In contrast, LN levels in the culture medium were significantly decreased when the cells were grown on DEAE-dextran or collagen-linked dextran as compared to the other substrates. FN levels were slightly lower in the culture medium of the cells grown on DEAE-dextran. Biosynthetic labeling followed by immunoprecipitation indicated that the reduction in LN was due, in part, to decreased biosynthesis. Previous studies have indicated that LN influences the behavior of epithelial cells in culture and that the cells, themselves, are a major source of the LN. The differences in $\mathrm{LN}$ production noted here indicate that the production of this ECM component is influenced by the substratum on which the cells are grown. These differences could contribute to alterations in biological properties that are known to be influenced by the substratum.

\section{INTRODUCTION}

Cell - cell and cell - substrate adhesion are critical to several biological processes including fertilization, embryogenesis, inflammation, wound healing, and tumor cell invasion. ${ }^{1}$ In addition to these in vivo processes, cultivation of most higher eukaryotic (anchorage-dependent) cells in vitro also requires adhesion to a substratum. Anchoragedependent cells do not attach directly to the substratum, but rather, attach and spread on an extracellular matrix

* Send communications to: James Varani, Ph.D., Department of Pathology, University of Michigan Medical School, Ann Arbor, Michigan 48109 .
(ECM), which is deposited onto the substratum. Components of the extracellular matrix include collagens of various types, soluble glyoproteins such as fibronectin (FN), laminin (LN), and thrombospondin (TSP) and proteoglycans such as heparan sulfate proteoglycan. ${ }^{2,3,4}$ While serum used in the culture medium may provide most of the FN initially deposited onto the substrate, ${ }^{5}$ the cells, themselves, are responsible for synthesizing $\mathrm{FN}$ and the other glycoprotein components of the matrix. ${ }^{6-17}$ The endogenouslysynthesized matrix components are secreted by the cells and incorporated into the developing matrix. The cells that produce the ECM molecules also express surface receptors for these components and interact with the matrix via these receptors. ${ }^{18-27}$ Recent studies have shown that the continued adhesion of cells to the substratum - as well as their proliferation - is dependent on endogenously-produced matrix molecules. ${ }^{28,29}$ In the present study, the production of ECM molecules by cells grown on a number of different substrates was examined. The authors report here that there are significant substrate-dependent differences in the production of glycoprotein components of the ECM by anchoragedependent cells. These differences in ECM production may contribute to the alterations in properties which occur when the substrate on which the cells are grown is changed. ${ }^{30-32}$

\section{MATERIALS AND METHODS}

\section{Cells}

Two human squamous carcinoma cell lines, designated as UM-SCC- 1 and UM-SCC-11B, were used in these studies. The isolation and characterization of these lines have been described previously. ${ }^{33}$ In the present study the cells were grown at $37^{\circ} \mathrm{C}$ and $5 \% \mathrm{CO}_{2}$. The growth medium was Minimal Essential Medium of Eagle with Earle's 
salts (MEM) supplemented with $15 \%$ fetal bovine serum, nonessential amino acids, $100 \mathrm{U}$ per $\mathrm{mL}$ of penicillin and $100 \mu \mathrm{g}$ per mL of streptomycin. The cells were subcultured by trypsinization as required. In certain experiments human diploid (foreskin) fibroblasts were used. The fibroblasts were grown in MEM supplemented with $10 \% \mathrm{fe}-$ tal bovine serum and used at between passage 1 and 15 .

\section{Substrates and Culture Conditions}

Six different substrates (all in microcarrier form) were used in these studies. These include microcarriers made of DEAE-dextran (Cytodex I) and collagen-linked dextran (Cytodex III), both obtained from Pharmacia (Piscataway, $\mathrm{NJ}$ ); collagen (Ventregel) from Ventrex Laboratories (Portland, ME), glass-coated (Biosil) and collagen-coated polystyrene plastic (SoloHill Engineering, Ann Arbor, MI) and polystyrene plastic (Biosilon) from GIBCO, (Grand Island, NY). Denatured pig skin type I collagen (gelatin) is the collagenous component in each of the collagen-containing substrates. Each substrate was prepared for use according to the recommendations of the respective manufacturer. Cultures were established in $35 \mathrm{~mm}$ bacteriological dishes using a sufficient amount of each substrate to provide approximately $30 \mathrm{~cm}^{2}$ of surface area. Cells were harvested from monolayer culture, diluted to contain $7.5 \times 10^{5}$ cells in $2 \mathrm{~mL}$ of culture medium and mixed with the microcarriers. The cultures were then incubated for 18-24 hours at $37^{\circ} \mathrm{C}$ and $5 \% \mathrm{CO}_{2}$. Following incubation, the cells were washed four times in serum-free culture medium and incubated for an additional period of time in MEM containing $10 \%$ fetal bovine serum or in serum-free MEM containing $200 \mu \mathrm{g}$ of bovine serum albumin (BSA) $/ \mathrm{mL}$. This culture medium was then harvested, separated from cells and microcarriers by centrifugation, and assayed for immunoreactive FN, LN or TSP as described below. The cells were then harvested and counted using a nuclei assay procedure. ${ }^{34}$

\section{Extracellular Matrix Molecules}

The ECM molecules utilized in these experiments included FN, TSP, and LN. Each was obtained and characterized as previously described. ${ }^{35}$ Briefly, human plasma FN was obtained from GIBCO. When examined by sodium dodecylsulfate-polyacrylamide gel electrophoresis (SDS-PAGE) under reducing conditions, a single band at $M_{r}=200 \mathrm{kD}$ was seen. FN reacted with monospecific polyclonal rabbit anti-FN antibodies (Accurate Scientific and Chemical Co., Westbury, NY) at dilutions up to $1: 10^{6}$ in enzyme-linked immunosorbent assay (ELISA) but did not react with anti-LN antibodies or anti-TSP antibodies. TSP was purified in the laboratory from outdated human plasma using Heparin-Sepharose affinity chromatography. ${ }^{36}$ The purified TSP migrated on SDS-polyacrylamide gels as a single band with a $M_{r}=180 \mathrm{kD}$ under reducing conditions. It reacted with rabbit anti-TSP antibodies ( $1: 1-1: 10^{6}$ dilutions) in ELISA but did not react with
anti-FN or anti-LN antibodies. LN was prepared from the Englebreth-Holm-Swarm (EHS) tumor by the method of Timpl et al. ${ }^{37}$ When examined by SDS-PAGE under reducing conditions, protein bands at $M_{r}=200 \mathrm{kD}$ and $400 \mathrm{kD}$ were seen. The laminin reacted by ELISA with monospecific polyclonal antil-LN antibodies at dilutions up to $1: 10^{6}$ but did not react with antibodies to TSP or FN. In some experiments, commercially available LN (Collaborative Research, Boston MA) was also used with similar results.

Rabbit polyclonal antibodies (whole sera or gamma globulin fractions of whole sera) to each of the ECM components were also used in these studies. These were obtained and characterized as described previously. ${ }^{35}$ Each antibody reacted with its appropriate antigen in ELISA but showed no cross-reactivity with the other ECM components. Normal rabbit serum or globulin was used as a control.

LN and TSP purified as described above were iodinated using immobilized chloramine $\mathrm{T}$ on nonporous polystyrene beads (Iodo-Beads, Pierce Chemical Co., Rockford, IL). The protein iodinations were done by Dr. James Smart (Department of Pathology, University of Michigan). Free iodide was removed by filtration on a Sephadex G25 column. ${ }^{125} \mathrm{I}$-LN and ${ }^{125} \mathrm{I}$-TSP with specific activities of $1-2 \mu \mathrm{Ci} / \mu \mathrm{g}$ were obtained. These values are similar to what we have reported previously. ${ }^{24,25}$ Both proteins retained most of their biological activity (i.e., ability to induce cellsubstrate adhesion of appropriate cells) after iodination. The iodinated proteins were used to assess LN and TSP adsorption to the various substrates.

\section{Enzyme-Linked Immunosorbent Assay (ELISA)}

ELISAs were used to quantitate the amount of immunoreactive $\mathrm{FN}, \mathrm{LN}$, or TSP present in the culture fluids of the cells. After clarification by centrifugation, the culture fluids prepared as described above were added in duplicate $(0.1 \mathrm{~mL}$ per well) to wells of a 96 -well plate (Falcon Plastics; Oxnard, CA). The plates were chosen from lots that had been preselected for acceptibility in ELISA. The culture fluids were incubated in the wells for 4 hours at $37^{\circ} \mathrm{C}$. Control culture medium which had been preincubated along with the cells served as the control. Purified FN, LN, or TSP $(0.1-0.0001 \mu \mathrm{g}$ per well) were incubated in the same medium to serve as a standard. After the 4-hour incubation, the supernatant fluids from the cells and the control fluids were removed from the assay plate and the ELISAs were carried out as described previously. ${ }^{38}$

\section{Biosynthetic Labeling}

Cells were grown on the various substrates as described above and 6-7 cultures were pooled to provide approximately $5 \times 10^{6}$ cells in a $100 \mathrm{~mm}$ culture dish. The cells were washed and incubated for 30 minutes in methioninefree, serum-free MEM (Flow Laboratories; McLean, VA) followed by a 60 -minute incubation in the same medium supplemented with $100 \mu \mathrm{Ci}$ per dish of ${ }^{35} \mathrm{~S}$-methionine 
(1000-1400 $\mu \mathrm{Ci} / \mu$ mole; NEN, Boston, MA). After the 60-minute biosynthetic pulse, the cells were lysed in a solution of phosphate-buffered saline (PBS) containing three detergents (1\% Triton $X-100,0.5 \%$ sodium deoxycholate and $0.1 \%$ SDS; all obtained from Sigma Chemical Co.) and protease inhibitors including $20 \mathrm{~m} M$ EDTA, $5 \mathrm{~m} M$ $N$-ethyl maleimide, $2 \mathrm{~m} M$ phenylmethysulfonyl fluoride and $10 \mu \mathrm{L} / 10 \mathrm{~mL}$ of a protease inhibitor cocktail containing: leupeptin, $1 \mathrm{mg} / \mathrm{mL}$; antipain, $2 \mathrm{mg} / \mathrm{mL}$; benzamidine, $10 \mathrm{mg} / \mathrm{mL}$; aprotinin, 10,000 kallikrein-inactivating units $/ \mathrm{mL}$; chymostatin, $1 \mathrm{mg} / \mathrm{mL}$; and pepstatin, $1 \mathrm{mg} / \mathrm{mL}$, as described by Ronnett et al. ${ }^{39}$ in studies on the insulin receptor. All of the protease inhibitors were obtained from Sigma Chemical $\mathrm{Co}$. The cell lysates were frozen at $-80^{\circ} \mathrm{C}$, thawed, and clarified by ultracentrifugation $(37000 \mathrm{~g}$ for $60 \mathrm{~min}$ ). Immunoreactive $\mathrm{LN}$ or TSP was precipitated with a 1:100 dilution of the rabbit anti-LN or anti-TSP and Protein A-Sepharose (Sigma Chemical Co.) according to the protocol of Ruddon et al.$^{40}$ Normal rabbit serum served as a control. The washed immunoprecipitates were eluted with boiling ( $5 \mathrm{~min}$ ) in twofold concentrated Laemmli SDSPAGE sample buffer ${ }^{41}$ containing $2 \% 2$-mercaptoethanol. The immunoprecipitated material was fractionated on a 3-10\% polyacrylamide gel employing the Laemmli system. Radioactive bands were visualized by fluorography with $E^{3}$ Hance (NEN), exposing the dried gels to X-ray film (Kodak XAR-2) for two days. Additionally, samples of the immunoprecipitates were counted directly for total radioactivity and compared to the amount of radioactivity in the original cell lysates precipitated with $10 \%$ (final) trichloroacetic acid.

\section{RESULTS}

\section{Quantitation of FN, LN, and TSP in the Culture Fluid by ELISA}

ELISAs were used to quantitate the amount of FN, LN, and TSP released into the culture fluids by cells grown on the different substrates. Cells were plated on the various substrates at $7.5 \times 10^{5}$ cells per group as described in the Materials and Methods section. After incubation for one day, the culture medium was removed. The cells were then washed four times with serum-free MEM and incubated for an additional two hours or 24 hours with $2 \mathrm{~mL}$ of MEM supplemented with $200 \mu \mathrm{g}$ of BSA $/ \mathrm{mL}$. The culture fluids were then harvested and assayed for immunoreactive FN, LN, and TSP. The cells were harvested and counted. Data from the UM-SCC-11B cells on six different substrates are shown in Table I. Data from the other squamous carcinoma line and the normal fibroblasts are shown in Table II. It can be seen that the amount of TSP recovered from the culture fluids varied only slightly as a function of the substrate on which the cells were grown. In contrast, the amount of LN recovered from the culture medium was dramatically lower when the cells were cultured on the DEAE-dextran and collagen-linked dextran substrates rela-
Table I. Immunoreactive LN, FN, and TSP in the culture fluid of UMSCC-11B cells grown on various substrates.

\begin{tabular}{lccc}
\hline & \multicolumn{3}{c}{$\begin{array}{c}\text { Immunoreactive LN, FN, or TSP } \\
\text { (ng/mL/1 }\end{array}$} \\
\cline { 2 - 5 } \multicolumn{1}{c}{ Substrate $^{\mathrm{a}}$} & $\mathrm{LN}$ & $\mathrm{FN}$ & TSP \\
\hline Plastic (2 hours) & $80 \pm 16$ & $1420 \pm 85$ & $195 \pm 35$ \\
Glass (2 hours) & $64 \pm 10$ & $1600 \pm 90$ & $330 \pm 10$ \\
Collagen (2 hours) & $68 \pm 4$ & $1170 \pm 150$ & $180 \pm 45$ \\
Collagen-coated plastic (2 hours) & $60 \pm 8$ & $1630 \pm 50$ & $445 \pm 35$ \\
Collagen-linked dextran (2 hours) & $4 \pm 2$ & $1150 \pm 25$ & $300 \pm 60$ \\
DEAE-dextran (2 hours) & $2 \pm 1$ & $1250 \pm 35$ & $350 \pm 50$ \\
Collagen-coated plastic (24 hours) & $238 \pm 10$ & Not done & Not done \\
DEAE-dextran (24 hours) & $20 \pm 5$ & Not done & Not done \\
\hline
\end{tabular}

${ }^{a}$ Each substrate was prepared as described in the Materials and Methods section and inoculated with $7.5 \times 10^{5}$ cells in $2-\mathrm{mL}$ cultures $(35-\mathrm{mm}$ bacteriological dishes). After incubation for one day the culture medium was removed and the cultures washed four times. Two $\mathrm{mL}$ of MEM supplemented with $200 \mu \mathrm{g}$ of BSA $/ \mathrm{mL}$ were added to each dish and the cells incubated for an additional two or 24 hours. The culture fluids were then harvested and analyzed for immunoreactive LN, FN, or TSP using ELISAs. Values were obtained directly from standard curves. After removing the culture fluid, cell numbers on each substrate were determined using a nuclei assay.

${ }^{b}$ Values represent average $n g$ of immunoreactive material \pm the differences between individual values and averages based on duplicate samples in a single experiment. The experiment was repeated three times with similar results.

tive to the others and the amount of FN recovered was slightly lower under the same conditions.

In an additional set of experiments, ELISAs were used to quantitate the amount of $\mathrm{LN}$ released into the culture medium by UM-SCC-11B cells in the presence of serum. The cells were grown on collagen-coated plastic and on DEAE-dextran for periods of time ranging from 1-5 days. After incubation, the culture medium was removed and the cells were washed four times with serum-free MEM. The cells were then incubated for an additional two hours or 24 hours in MEM supplemented with $10 \%$ fetal bovine serum. The culture fluids were harvested and assayed for immunoreactive LN. Substrate-dependent differences in the serum-containing culture medium were even greater than the differences observed under serum-free conditions. In the 2-hour culture fluid from the cells grown on collagencoated plastic, there was approximately $360 \mathrm{ng}$ of immunoreactive $\mathrm{LN}$ per culture as compared to $5 \mathrm{ng}$ in the cuiture fluid from the cells grown on DEAE-dextran. At 24 hours, there was approximately $2000 \mathrm{ng}$ of immunoreactive material in the culture fluid from the cells grown on collagencoated plastic as compared to $22 \mathrm{ng}$ in the culture fluid from the cells grown on DEAE-dextran (Fig. 1). These substrate-dependent differences remained over time. UMSCC-11B cells grown for up to five days on the same substrates produced comparable amounts of immunoreactive LN per 24-hour period as the amounts shown in Figure 1 (not shown). 
Table II. Immunoreactive $\mathrm{LN}$ and $\mathrm{FN}$ in the culture fluid of cells grown on various substrates.

\begin{tabular}{llcc}
\hline & & \multicolumn{2}{c}{$\begin{array}{c}\text { Immunoreactive LN or FN } \\
\left(\mathrm{ng} / \mathrm{mL} / 1 \times 10^{6} \text { cells }\right)^{\mathrm{b}}\end{array}$} \\
\cline { 3 - 4 } \multicolumn{1}{c}{ Cell type } & \multicolumn{1}{c}{ Substrate } & $\mathrm{LN}$ & $\mathrm{FN}$ \\
\hline UM-SCC-1 & plastic & $53 \pm 2$ & $1150 \pm 20$ \\
(squamous carcinoma) & glass & $60 \pm 4$ & $1500 \pm 15$ \\
& collagen-coated plastic & $57 \pm 8$ & $1485 \pm 70$ \\
Human foreskin & DEAE-dextran & $6 \pm 3$ & $1040 \pm 70$ \\
fibroblasts & plastic & $65 \pm 5$ & $1005 \pm 100$ \\
& glass & $60 \pm 8$ & $1300 \pm 150$ \\
& collagen-coated plastic & Not done & Not done \\
& DEAE-dextran & $10 \pm 5$ & $500 \pm 55$ \\
\hline
\end{tabular}

\footnotetext{
a Each substrate was prepared as described in the Materials and Methods section and inoculated with $7.5 \times 10^{5}$ cells in 2-mL cultures (35-mm bacteriological dishes). After incubation for one day the culture medium was removed and the cultures washed four times. Two $\mathrm{mL}$ of MEM supplemented with $200 \mu \mathrm{g}$ of $\mathrm{BSA} / \mathrm{mL}$ were added to each dish and the cells incubated for an additional two hours. The 2-hour culture fluids were then harvested and analyzed for immunoreactive LN or FN using ELISAs. Values were obtained directly from standard curves. After removing the culture fluid, cell numbers on each substrate were determined using a nuclei assay.

${ }^{b}$ Values represent average $\mathrm{ng}$ of immunoreactive material \pm the differences between individual values and averages based on duplicate samples in a single experiment. Each cell type was examined two times with similar results.
}

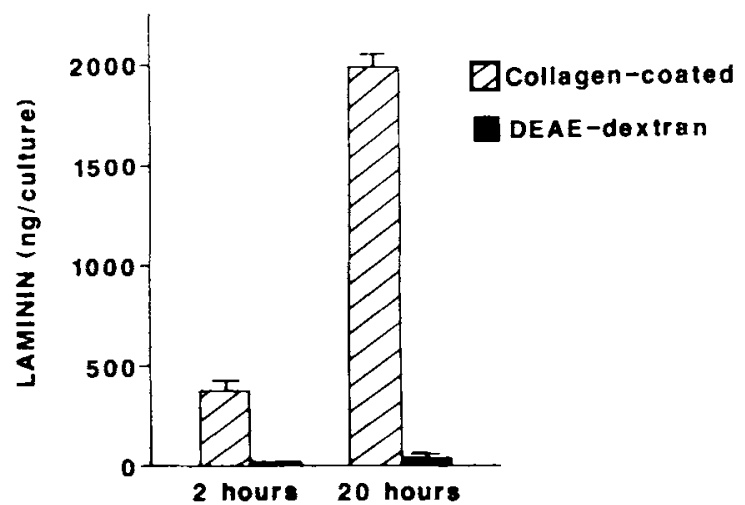

Figure 1. Immunoreactive $L N$ in the culture fluid of UM-SCC-11B cells grown on collagen-coated plastic and DEAE-dextran. The substrates were prepared as described in the Materials and Methods section and inoculated with $7.5 \times 10^{5}$ cells in $2-\mathrm{mL}$ cultures. After incubation for one day the culture medium was removed and the cultures washed four times. Two $\mathrm{mL}$ of MEM supplemented with $10 \%$ fetal bovine serum were added to each dish and the cells incubated for an additional two or 24 hours. The culture fluids were then harvested and analyzed for immunoreactive LN using ELISAs. Values were obtained directly from standard curves. After removing the culture fluids, cell numbers were determined using a nuclei assay. Values shown represent average ng of immunoreactive material \pm the differences between individual values and averages based on duplicate samples in a single experiment. The experiment was repeated three times with similar results.

\section{Biosynthetic Labeling}

The reduction in immunoreactive $\mathrm{LN}$ in the culture fluid of the cells grown on DEAE-dextran and collagen-linked dextran as compared to the other substrates could result from decreased biosynthesis. Alternatively, a higher rate of adsorption of the LN to the DEAE-dextran and collagenlinked dextran could account for the observed difference. A number of experiments were done to address this issue.
First, cells grown on DEAE-dextran and cells grown on collagen-coated plastic were compared for LN and TSP biosynthesis. UM-SCC-11B cells grown on the two substrates were labeled with ${ }^{35} S$-methionine for one hour as described in the Methods section. Extracts were prepared from the labeled cells and examined for total ${ }^{35} S$-methionine incorporation into trichloroacetic acidprecipitable material and into anti-LN and anti-TSP precipitable material. Total protein synthesis was reduced slightly (approximately $34 \%$ based on differences in isotope incorporation) in the cells grown on DEAE-dextran as compared to the cells grown on collagen-coated plastic. As a fraction of total protein synthesized, there was no difference in TSP biosynthesis between the cells on the two substrates (Table III). In contrast, laminin biosynthesis was reduced by approximately $67 \%$ in the cells grown on DEAE-

Table III. LN and TSP biosynthesis by UM-SCC-11B cells grown on collagen-coated plastic and DEAE-dextran. ${ }^{2}$

\begin{tabular}{lcc}
\hline & \multicolumn{2}{c}{$\begin{array}{c}\text { Immunoreactive LN or TSP } \\
(\% \text { of total protein })^{\mathrm{b}}\end{array}$} \\
\cline { 2 - 3 } \multicolumn{1}{c}{ Substrate } & $\mathrm{LN}$ & $\mathrm{TSP}$ \\
\hline Collagen-coated plastic & $0.31 \pm 0.05$ & $0.58 \pm 0.10$ \\
DEAE-dextran & $0.13 \pm 0.02$ & $0.50 \pm 0.05$ \\
\hline
\end{tabular}

Cells grown on the two substrates were examined for LN and TSP biosynthesis using ${ }^{35} S$-methionine incorporation into protein followed by detergent extraction and immunoprecipitation.

${ }^{b}$ Samples of each cell lysate were precipitated with $10 \%$ trichloroacetic acid (TCA) to obtain total CPM of ${ }^{35} S$-methionine incorporated into protein. Samples of the same lysates were immunoprecipitated with antibodies to LN or TSP. The ratios of CPM in the immunoprecipitates to TCA-precipitable CPM were determined. The values shown are based on a single experiment. This experiment was repeated three times with similar results. 
A B C D

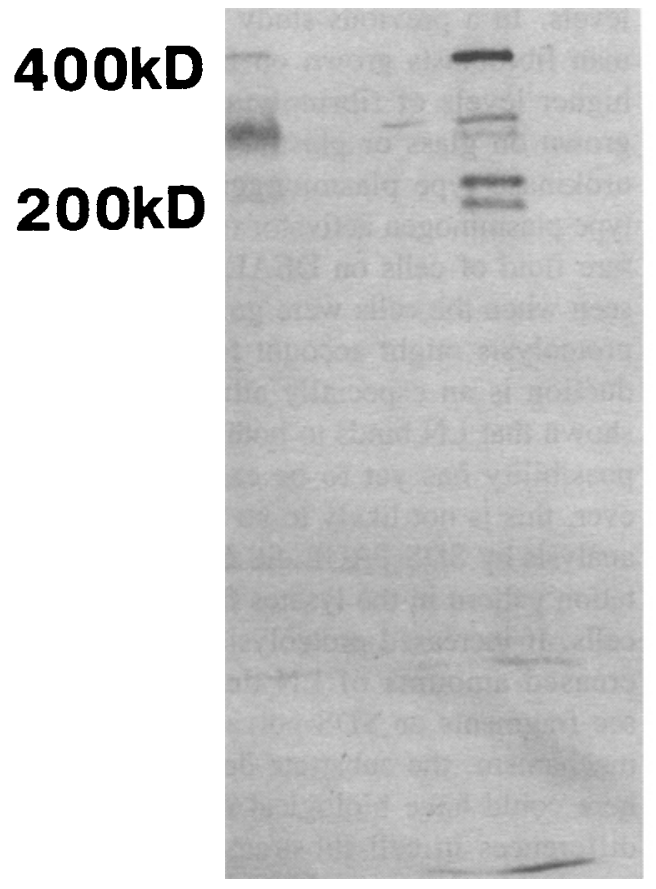

A B

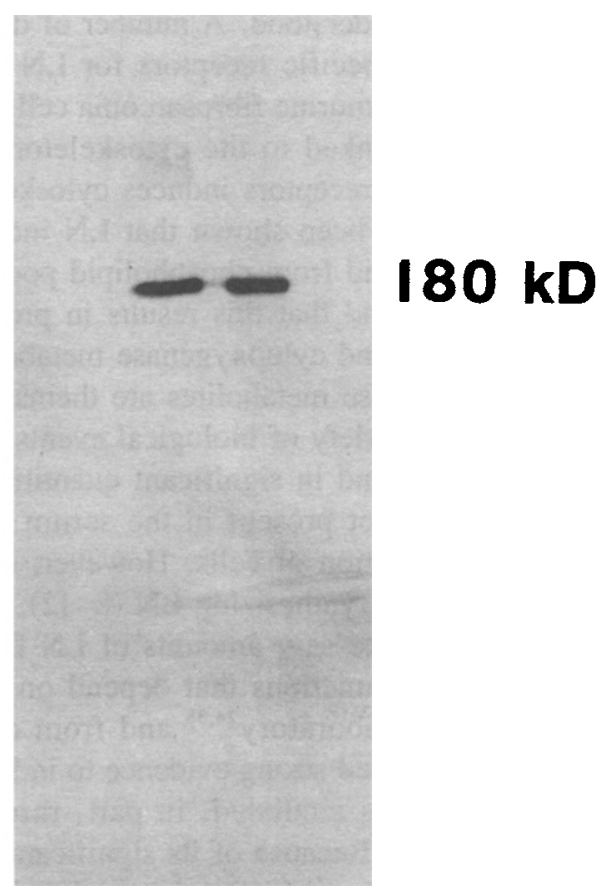

Figure 2. Biosynthesis of LN and TSP by UM-SCC-11B cells. Cells were examined for ECM component biosynthesis by ${ }^{35} S$-methionine incorporation into protein followed by immuno-precipitation, SDS-PAGE and autoradiography. A 3-10\% gradient gel was used and the samples were electrophoresced in the presence of $2 \% 2$ mercaptoethanal. The molecular profile of $\mathrm{LN}$ is shown in the left-side figure. A single protein band at $400 \mathrm{kDa}$ and a doublet at $200 \mathrm{kDa}$ are seen. Lane A, DEAE-dextran/anti-LN; Lane B, DEAE-dextran/normal rabbit serum; Lane C, collagen-coated plastic/normal rabbit serum; Lane D, collagen-coated plastic/anti-LN. The molecular profile of TSP is shown in the right-side figure. A single protein band at $180 \mathrm{kDa}$ is seen. Lane A, DEAE-dextran/anti-TSP; Lane B, collagen-coated plastic/anti-TSP.

dextran as compared to cells grown on collagen-coated plastic (Table III). In spite of the quantitative differences, there appeared to be no significant difference in the molecular forms of either LN or TSP as a function of substrate (Fig. 2).

\section{LN and TSP Adsorption to Different Substrates}

DEAE-dextran, glass, and collagen-coated plastic substrates were incubated with serum-containing culture medium (without cells) for one day. Following this, they were washed four times in serum-free culture medium and incubated for two hours in MEM containing $200 \mu \mathrm{g}$ of $\mathrm{BSA} / \mathrm{mL}$ and iodinated $\mathrm{LN}$ or TSP ( $1 \mu \mathrm{g}$ per reaction). At the end of the incubation period, the amounts of $L N$ and TSP bound to each substrate were determined. Under the conditions of the assay, there was no significant difference in $\mathrm{LN}$ adsorption to the different substrates (Fig. 3). Likewise, there was no difference in TSP binding to the collagen-coated plastic microcarriers and DEAE-dextran microcarriers (not shown).

\section{DISCUSSION}

ECM components, especially $L N$, play critical roles in adhesion, motility, proliferation, and differentiation of

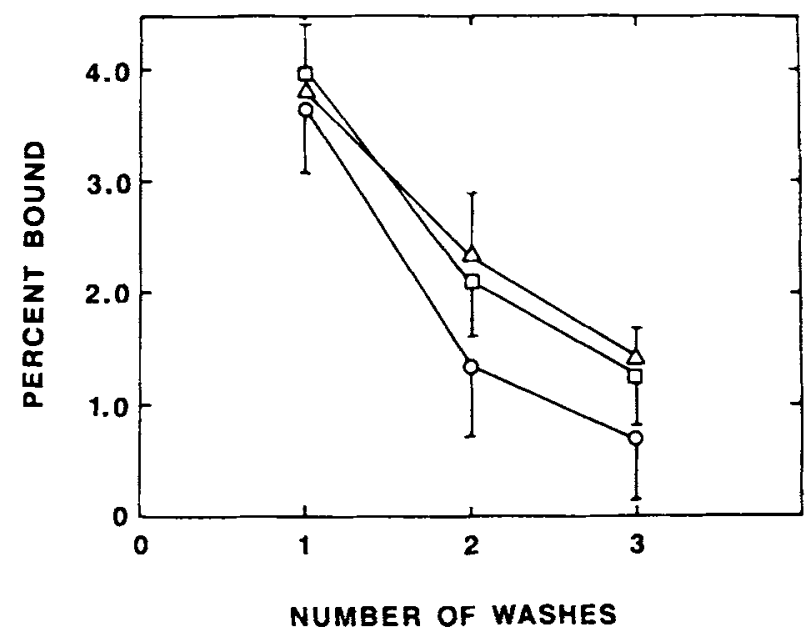

Figure 3. Adsorption of ${ }^{125} \mathrm{I}-\mathrm{LN}$ to various substrates. The substrates were incubated in MEM containing $10 \%$ fetal bovine serum for one day at $37^{\circ} \mathrm{C}$. Following this, they were washed four times in serum-free MEM and incubated for two hours in MEM supplemented with $200 \mu \mathrm{g}$ of $\mathrm{BSA} / \mathrm{mL}$ with $1 \mu \mathrm{g}$ of $\mathrm{LN}\left(1 \times 10^{6} \mathrm{cpm}\right)$. Following the 2 -hour incubation, the substrates were separated from the incubation medium by centrifugation. The radioactivity remaining associated with each substrate was determined after 1,2 , or 3 washes. Values represent means \pm standard deviations based on four samples in a single experiment. The experiment was repeated three times with similar results. (Collagen-coated plastic, $\square-\square$; DEAE-dextran, $\Delta-\Delta$; glass, $0-0$ ). 
anchorage-dependent epithelial cells in vitro (see references 42 and 43 for reviews). The molecular basis for these effects are not fully understood. A number of different types of cells express specific receptors for $\mathrm{LN}$ (2024). It has been shown with murine fibrosarcoma cells that LN receptors are directly linked to the cytoskeleton and that binding of $\mathrm{LN}$ to these receptors induces cytoskeletal reorganization. ${ }^{44}$ It has also been shown that $\mathrm{LN}$ induces the release of arachidonic acid from phospholipid pools in murine fibrosarcoma cells and that this results in production of both lipooxygenase and cylooxygenase metabolites from arachidonic acid. ${ }^{45}$ These metabolites are themselves potent intermediaries in a variety of biological events.

Unlike FN, LN is not found in significant quantities in plasma. ${ }^{42}$ Therefore, it is not present in the serum used routinely for in vitro cultivation of cells. However, since most cells are capable of biosynthesizing LN (8-12), they are capable of producing necessary amounts of $\mathrm{LN}$ for in vitro growth and for other functions that depend on $\mathrm{LN}$. Studies from the authors' laboratory ${ }^{24,38}$ and from other laboratories ${ }^{11,12,29}$ have provided strong evidence to indicate that cell adhesion in vitro is mediated, in part, through endogenously-produced LN. Because of its significance to biological behavior, how $\mathrm{LN}$ production is regulated and how endogenously-produced LN influences cell behavior are of interest. The influence of the substratum on the production of LN by human cells is the subject of this report. Here it is shown that LN production by two different squamous carcinoma cell lines and by diploid fibroblasts is dramatically decreased when the cells are grown on DEAE-dextran or collagen-linked dextran as compared to several other substrates. The amount of $\mathrm{LN}$ in the culture fluid of the cells grown on DEAE-dextran is decreased by up to $99 \%$ as indicated by ELISA. FN production is also inhibited on the same substrate although to a much smaller degree. In contrast, TSP production varies only slightly with the substrate.

The cellular and molecular basis for the substratedependent differences in LN production are not understood at present. In part, they appear to be due to altered biosynthesis. Biosynthetic labeling and immunoprecipitation indicated an approximately $67 \%$ reduction in $\mathrm{LN}$ synthesis by cells grown on DEAE-dextran during a 1-hour pulse relative to total protein synthesis. This was in addition to an overall reduction in protein synthesis of approximately $34 \%$ on the same substrate.

Altered capacity of the different substrates to bind secreted LN could also account for the reduction seen on the DEAE-dextran substrate. It might be expected, in fact, that the highly-charged DEAE-dextran molecule would be more effective at binding secreted proteins than the other substrates. Attempts to demonstrate this, however, with iodinated LN did not support this. When the DEAE-dextran substrate was compared to collagen-coated plastic for $\mathrm{LN}$ or TSP binding under conditions that mimicked those employed with cells, virtually identical amounts of both ECM components were absorbed by the two substrates.
Another possibility is that there are substrate-dependent differences in proteolysis which contribute to altered LN levels. In a previous study it was shown that normal human fibroblasts grown on DEAE-dextran produced much higher levels of fibrinolytic activity than the same cells grown on glass or plastic. ${ }^{31}$ Significant amounts of both urokinase type plasminogen activator (u-PA) and tissue type plasminogen activator (t-PA) were detected in the culture fluid of cells on DEAE-dextran while only u-PA was seen when the cells were grown on glass. That differential proteolysis might account for the differences in LN production is an especially attractive idea since it has been shown that $\mathrm{LN}$ binds to both plasminogen and t-PA. ${ }^{46}$ This possibility has yet to be examined systematically. However, this is not likely to be the entire explanation because analysis by SDS-PAGE did not reveal any unique fragmentation pattern in the lysates from the DEAE-dextran grown cells. If increased proteolysis were responsible for the decreased amounts of LN detected, one might expect to see fragments on SDS-polyacrylamide gels. Regardless of mechanism, the substrate-dependent differences observed here could have biological relevance. The well-described differences in cell-substrate adhesion, growth rates, and morphology between cells grown on DEAE-dextran and on glass or plastic ${ }^{30-32}$ could be a reflection, in part, of differences in matrix molecule production and utilization.

This study was supported in part by grant CA43352 from the USPHS, by grant PDT-324 from the American Cancer Society, by a grant from the Veteran's Administration and by a grant from the Michigan Department of Commerce.

\section{References}

1. E. Roos, Biochim. Biophys. Acta., 738, 263-284 (1984).

2. N. A. Kefalides, Renal. Physiol., 4, 57-71 (1981).

3. N. A. Kefalides, R. Alper, and C. C. Clark, Int. Rev. Cytol., 61, 167-183 (1979).

4. A. Martinez-Hernandez, P. S. Amenta, Lab. Invest., 48, 656-667 (1983).

5. F. G. Grinnel, M. Feld, and D. Minter, Cell, 19, 517-525 (1980).

6. H. S. Smith, J. L. Riggs, and M. W. Mosesson, Cancer Res., 39, 4138-4144 (1979).

7. P. Taylor-Papadimitrious, I. Burchell, and I. Hurst, Cancer Res., 41, 2491-2500 (1981).

8. B. P. Peters, R. J. Hartle, R. F. Krzesicki, T. G. Kroll, F. Perini, J. E. Balun, I. J. Goldstein, and R. W. Ruddon, J. Biol. Chem., 260, 14732-14740 (1985).

9. S. L. Palm and L. T. Furcht, J. Cell. Biol., 96, 1218-1226 (1983).

10. S. E. G. Fligiel, K. A. Layboum, B. P. Peters, R. W. Ruddon, J.C. Hiserodt, and J. Varani, Clin. Expl. Metastasis, 4, 259-272 (1986).

11. E. Rampoldi, L. Larizza, L. Doneda, and S. Barlatil, Tumori, 419423 (1985).

12. K. Alitalo, A. Vaheri, T. Krieg, and R. Timpl, Eur J. Biochem., 109, 247-255 (1980).

13. E. A. Jaffe, J. T. Ruggiero, L. L. K. Leung, M. J. Doyle, P. J. McKeown-Longo and D. F. Mosher, Proc. Natl. Acad. Sci. USA, 80, 998-1002 (1983).

14. G. J. Raugi, S. M. Mumby, D. Abbott-Brown, and P. Bornstein, J. Cell. Biol., 95, 351-354 (1982).

15. D. F. Mosher, M.J. Doyle, and E. A. Jaffe, J. Cell. Biol, 93, 343348 (1982). 
16. H. Sage, F. M. Farin, G. E. Striker, A. B. Fisher, Biochemistry, 22, 2148-2155 (1983).

17. J. McPherson, H. Sage, and P. Bornstein, J. Biol. Chem., 256, $11330-11336$ (1981).

18. S. K. Akiyama, and K. M. Yamada, J. Biol. Chem., 260, 44924500 (1985).

19. J. M. Gardner and R. O. Hynes, Cell, 42, 439-448 (1985).

20. V. P. Terranova, C. N. Rao, T. Kalebic, I. M. Margulies, and L. A. Liotta, Proc. Natl. Acad. Sci. USA, 80, 444-448 (1983).

21. S. H. Barsky, C. N. Rao, D. Hyams, and L. A. Liotta, Breast Cancer Res. Treatment, 4, 181-188 (1984).

22. N. C. Rao, S. H. Barsky, V. P. Terranova, and L. A. Liotta, Biochem. Biophys. Res. Comm., 111, 804-808 (1983).

23. H. L. Malinoff and M.S. Wicha, J. Cell. Biol., 96, 1475-1479 (1983).

24. H. L. Malinoff, J. P. McCoy, J. Varani, and M. S. Wicha, Int. J. Cancer, 33, 651-655 (1984).

25. B. L. Riser, J. Varani, K. O'Rourke, and V. M. Dixit, Exp. Cell. Res., 174, 319-329 (1988)

26. J. E. Murphy-Ullich and D. F. Mosher, J. Cell. Biol., 105, 1604 1611 (1987)

27. R. L. Silverstein and R. L. Nachmam, J. Clin. Invest., 79, 867-874 (1987)

28. J. R. Couchman, M. Hook, D. A. Rees, and R. Timpl, J. Cell. Biol., 96, 177-183 (1983).

29. F. J. Bober, D. E. Birk, and K. Raska, Lab. Invest., 56, 37-43 (1987).

30. J. Varani, M. Dame, J. Rediske, and W. A. Hillegas, J. Biol. Stand., $13,67-76$ (1985)

31. J. Varani, J. D. Hasday, R. G. Sitrin, P. G. Brubaker, and W. A. Hillegas, In Vitro Cell Develop. Biol., 22, 575-582 (1986).
32. J. Varani, M.J. Bendelow, J. H. Chun, and W. A. Hillegas, J. Biol. Stand., 14, 331-336 (1986).

33. J. Varani, V.M. Dixit, S.E. G. Fligiel, P. E. McKeever, and T.E. Carey, Exp. Cell. Res., 167, 376-390 (1986).

34. K. Sanford, W. Earle, V. Evans, J. Nat. Cancer. Inst., 11, 773-794 (1950).

35. J. Varani, B. J. Nickoloff, B. L. Riser, R. S. Mitra, K. O'Rourke and V. M. Dixit, J. Clin. Invest., 81, 1537-1544 (1988).

36. V. M. Dixit, G. A. Grant, S. A. Santoro, and W. A. Frazier, J. Biol. Chem., 259, 10100-10105 (1984).

37. R. Timpl, H. Rohde, P. G. Robey, S. I. Rennard, J. M. Foidart, G. R. Martin, J. Biol. Chem., 254, 9933-9937 (1979).

38. J. Varani, E. J. Lovett, J. P. McCoy, S. Shibata, D. Maddox, I. J. Goldstein, and M. Wicha, Am. J. Pathol., 111, 27-34 (1983).

39. G. V. Ronnett, V. P. Knutson, R. A. Kohnski, T. L. Simpson, and M. D. Lane, J. Biol. Chem., 259, 4566-4576 (1984).

40. R. W. Ruddon, C. A. Hanson and N. J. Addison, Proc. Natl. Acad. Sci. USA, 76, 5143-5147 (1979).

41. U. K. Laemmli, Nature, 227, 680-685 (1970).

42. K. Von der Mark, and U. Kuhl, Biochim. Biophys. Acta, 823, 147 $160(1985)$

43. H. K. Kleinman, F. B. Cannon, G. W. Laurie, J. R. Hassell, M. Aumailley, V.P. Terranova, G. R. Martin, and M. DuBois-Daleg, J. Cell. Biochem., 28, 317-325 (1985).

44. S. S. Brown, H. L. Malinoff, and M. S. Wicha, Proc. Natl. Acad. Sci. USA, 80, 5927-5932 (1983).

45. S. E. G. Fligiel, P. Perone, and J. Varani, Int. J. Cancer, 36, 383388 (1985).

46. E.-M. Salomen, A. Zitting, and A. Vaheri, FEBS Letter, 172, 29-32 (1984). 